\title{
Public Participation in the Development of Leading Sector of Agriculture and Fisheries in Pangkep Regency
}

\author{
Nuryanti Mustari ${ }^{1}$ \\ Lukman Hakim² \\ Public Administration, FISIP Universitas Muhammadiyah Makassar, Gedung lqra Lt. 5 Jl. Sultan Alauddin No. 259 Makassar \\ E-mail: nuryantimustari07@gmail.com, matematikawanmuslim@gmail.com
}

\section{Doi:10.5901/mjss.2015.v6n6s2p340}

\begin{abstract}
There are still many leading sectors that are not well managed by local governments. In fact, they can contribute to the economic growth and the improvement of the well-being of the communities. They resulted in the low income derived from an area. Dependence of local governments to the central government is getting higher in managing area income and expenditure estimate. Therefore, this research seeks to observe this issue specifically. The problem is to what extent public participation helps the success of each program development for the potential of the region, especially in the agricultural and fisheries sectors. This research used a descriptive qualitative method. The qualitative approach using observation and in-depth interviews are used to obtain valid data and information. It is intended to explain comprehensively about community participation in developing leading sector sources owned by regions. The results showed that the public is less involved in the excavation of the notion in developing the potential of the regions. Maintenance and management of plantation commodity have been carried out maximally. However, it is often constrained by marketing the commodity because the public assume that they are less given the space to be able to market the results of such natural resources properly.
\end{abstract}

Keywords: Public participation, development, regional potential

\section{Introduction}

The nature of the autonomous region is in accordance with the Law No. 32 of 2004 concerning local governments of Article 13 Paragraph 14 (2) and paragraph (2) and the Law No. 33 of 2004. These regulations reveal that financial equalization between the central government and the local government is distributing the authority based on the principle of decentralization, deco centration and administration tasks at the level of government in order to encourage regional initiatives to establish its independence within the Unitary State of the Republic of Indonesia.

Through a scheme of the autonomous region, the local government together with the private parties and the public will increasingly play a role in improving its competitiveness in order to realize the socio-economic prosperity of the public in its region. The position of the region which is increasingly important in determining its competitiveness shows the implementation of decentralization policy that is increasingly urgent in order to reform the government administration, the development and the quality of public services. Referring to the implementation of regional autonomy and the urgency that stimulate the income derived from an area, the region should develop its own resources and reduce the dependency to the central government.

Through the government regulation No. 6/2008 on the evaluation guidelines for local governance, then the local governments should strive to build up its territory oriented on increasing the prosperity of the community, community service, and the competitiveness of regions. The competitiveness development of the leading sectors can be seen in the sectors that are most involving the lives of communities and the sectors the are most absorbing labour from natural resources, artificial resources, and human resources that can raise the competitiveness of the region.

Development of leading sectors belonging to the region is reflected in the vision and mission of the areas contained in the regional long-term plan or RPJPD and the regional medium-term development plan or RPJMD. Besides, the leading sectors reflected in the gross regional domestic product or GRDP. It is a reflection of the development of macroeconomics in an area, which describes in detail the supporting power of the sector and the sub-sector of the real potential to GRDP. It means that if the area wants to spur its competitiveness based on its potential, the map that is used as guideline development is through the development of sector and sub-sector of GRDP. The potential of the area that is intended in this study is the potential for agriculture and marine. 
There are still many leading sectors that are not well managed by local governments. In fact, they can contribute to the economic growth and the improvement of the well-being of the communities. They resulted in the low income derived from an area. Dependence of local governments to the central government is getting higher in managing area income and expenditure estimate. Variables related to the potential of the area that is less managed is low levels of public participation to help the success of any development program for the potential of the area.

\subsection{Development of leading sector of the area that has competitiveness}

The economic potential of the area is defined by Suparmoko (2002) as "the ability of the economy in the area that is possible and feasible to be developed so that it will continue to develop into a source of livelihood of the local people. In addition, it can encourage the regional economy as a whole to grow continuously. Sumihardjo (2008) describes that the development of leading sector owned by the region is reflected in the vision and mission of the region contained in RPJPD and RPJMD. In RPJPD and RPJMD, priority areas are visible in each program of the district/city in strengthening the development of leading sector. In addition, Area Income and Expenditure Estimates should reflect the programs and the development goals. A plan will be operational if the budget is available. It is the government's efforts in developing the potential of each region contained in the local development planning.

Governance in the field of development is basically the key to the successful development of local economic potential to strengthen regional competitiveness. A region that has a leading sector provides its own peculiarities that do not exist in other regions. Thus, this leading sector can be said as a basis activity (Triyuwono \& Yustika, 2003).

The implementation of regional autonomy carries implications for economic growth, inter-regional equity, and the search for sources of financing for development by digging the potential of the area. Thus, the economic development of the region largely determined by regional policy in determining the priority sectors for economic growth in the region. Glasson cited in Tomo (2012) reveals that the prosperity of a region is different from other regions. The difference is caused by the difference in its economic structure, and this factor is a major factor. A regional change to be more prosperous conditions depends on the efforts in the region of producing goods, services, and development efforts that are needed. Based on the theory of the economic base, the main factor of economic growth in a region is directly related to the demand for goods and services from outside the region (Arsyad cited in Tomo, 2012). The growth of industries that use local sources, including labor and raw materials for export will produce a wealth of the area and job creation. Therefore, regional development requires proper planning and strategy as well as the local government apparatus that are a tough and innovative because each region has different circumstances. Each region has its own characteristics in economic growth and potential.

The leading sectors of the region will be explored and well managed if they are supported by public participation. Public as residents can find out the sectors of the industry which can be used as leading sectors of regional potential and can produce additional revenue for them. Public participation is a development approach in public empowerment programs aimed at improving regional economic growth characterized by the magnitude of the Regional Gross Domestic Product or GDP. GDP will have an effect on increasing employment and tackling unemployment that often trigger social conflicts in society.

Some experts express the importance of public participation to involve in the decision-making process, to involve in of implementation of activities, to enjoy the results of these activities, and to participate in evaluating (Uphoff, 1992). Participation is a process in which various actors (stakeholders) can influence and share authority in determining development initiatives, decisions and allocation of various resources that affect them (Bank Dunia, 2007).

Participation must take place with the willingness and awareness to be mobilized. Thus, they know the importance of an active role in developing the potential of the region. Mubyarto (1984) directs that the public participation is always aiming to help the success of each program according to the ability of everyone without compromising self-interest. Likewise Nelson in Bryant and White (1982) views the importance of public participation to be directed in the planning and implementation of development called participation in the administrative process. The increasing public participation aims at building initiative in which each person or group of people participates horizontally between one with the other either in doing business together or in doing activities with other parties.

The development of public participation in development depends on the political will of the ruling government. In practice, the participatory process should start from the identification, stakeholder analysis, and consultation at the local level, designing development programs (program strategy, investment program, financing programs, and institutional development program), supervision, monitoring and evaluation. Thus, the participatory development in community development is expected always to appear in every excavation of the aspirations, needs, consultation, agreement, and decision making. Based on the idea of a variety of sources, we can conclude that the government right now should 
consider involving the public in any strategic action. Today, the public is getting smarter and more literate administration than ever before. Public already has the bargaining power to obtain information on all things related to them. In building participation in the autonomy era, the public should be considered as partners in running the local government and increasing the sense of belonging to be a local community, particularly to the potential of the area. If the public feel that they have a potential of the area, they will seek to maintain and develop it together, and the feeling of love will also appear on the potential of their area.

The aims of the study there are still many leading sectors that are not well managed by local governments. In fact, they can contribute to the economic growth and the improvement of the well-being of the communities. They resulted in the low income derived from an area. Dependence of local governments to the central government is getting higher in managing area income and expenditure estimate. One of the variables that cause the optimal management of the potential of the region, including: the low level of community participation to support the success of each development potential of the region's program. Therefore, this research seeks to observe this issue specifically.

\section{Method}

\subsection{Location and Sample of the Research}

This research was conducted in Pangkep Regency South Sulawesi. The research location was determined intentionally (purposive sampling) with some considerations. Pangkep has characteristics, diversity, vision and mission in terms of the capability of personnel, resources potential of the region, and sociocultural. This region has a diversity of leading natural resources. Location of the region represents the central region of South Sulawesi province. Pangkep has the natural resources of the fisheries and agriculture sector that are very of potential to be developed.

\subsection{Research Approach, Data Collection, and Data Analysis}

A qualitative approach was used to analyze public participation in developing the potential of the regions. Public participation has different socio-cultural characteristics in developing the potential of the region. Meanwhile, a survey of potential sources in the research area is intended to analyze comprehensively and describe the natural power resources, artificial resources and development that is owned. Among these potential sources, it will be identified sources of featured potential areas. These sources have competitiveness and are enthused by the public. They involve the lives of many people. In addition, they create many job opportunities. Thus, the research approach will provide a description, insight, whole, and exhaustive of the discussed issues. There were three steps of data analysis in this research, namely data reduction, data display, conclusion drawing and verification

\section{Results and Discussion}

\subsection{Description of Research Area}

Pangkep Regency is located on the west coast of South Sulawesi province. The northern part borders with Barru regency. The southern part borders with Maros regency. The eastern part borders with Bone. The western part borders with East Kalimantan, Madura, Nusa Tenggara Barat, and Bali/Selat Makasar. Pangkep has an area of $1112.29 \mathrm{~km} 2$. Lowland area is 73721 ha of coastline stretching from west to east consisting of rice fields, farms, marshes, and ponds. Most of the population work in the sector of agriculture, plantations, forestry, hunting, and fishing. There are 45.167 people industrial sector. There are 12.835 people in the sector of trading namely restaurant and accommodation services. There are 23.799 people in the social sector. There are 28.643 people in the individual sector. The others are 18.659 people. In the field of fisheries, all of the public especially officials have known leading potentials in Pangkep particularly in the field of agriculture and fisheries called boledong (bolu, lemo dan doang/ fish, pomelo and shrimp).

Potential areas of agriculture, especially rice commodity in 2010-2011 has increased. Likewise, horticulture types of vegetables, such as peppers, fruits and plantation commodities such as cashew, pecan, coconut, cotton, and coffee as the mainstay crops also is increased

\subsection{Economic Structure in Pangkajene and Islands District}

Until 2012, the economy in Pangkep Regency is still dominated by sectors of the processing industry. In 2012, the role of the processing industry sector toward the gross domestic product was 58,86 percent. The agricultural sector contributes 
the second largest, namely 14, 03 percent. The services sector is the third ranking that is 13 percent. In the region of the Islands, marine and fisheries potential is very abundant. In addition, the natural wealth of the mine excavated materials gives meaning to the smooth the pulse of the economy of this area. Overall the economic structure in Pangkajene and Islands District can be described in the following table

Table 1. The percentage contribution of GDP per economic sector on the basis of prices in 2009-2012

\begin{tabular}{|c|l|c|c|c|c|}
\hline \multirow{2}{*}{ No. } & \multirow{2}{*}{ Business Field } & \multicolumn{4}{|c|}{ Applicable year } \\
\cline { 3 - 6 } & 2009 & $\mathbf{2 0 1 0}$ & $\mathbf{2 0 1 1}$ & $\mathbf{2 0 1 2}$ \\
\hline 1. & agriculture & 19,72 & 19,18 & 16,94 & 14,03 \\
\hline 2. & Mining and Quarrying & 6,04 & 5,47 & 4,99 & 4,14 \\
\hline 3. & Processing Industry & 45,67 & 44,99 & 50,78 & 56,86 \\
\hline 4. & Electricity, Gas and Water & 0,36 & 0,34 & 0,29 & 0,25 \\
\hline 5. & Building & 2,83 & 2,80 & 2,56 & 2,46 \\
\hline 6. & Trading, Hotels and Restaurants & 4,93 & 4,86 & 4,37 & 4,04 \\
\hline 7. & Transportation and Communication & 3,41 & 3,23 & 2,90 & 2,53 \\
\hline 8. & Finance, Leasing and Services & 2,94 & 3,10 & 2,81 & 2,69 \\
\hline 9. & Services & 14,09 & 16,03 & 14,38 & 13,00 \\
\hline 10. & GDP & 100 & 100 & 100 & 100 \\
\hline
\end{tabular}

Source: Central Bureau of Statistics in Pangkep Regency, 2013(10)

\subsection{The Potential in the Fisheries Sector}

Pangkajene and Islands district has water resources that is rich, valuable, and abundant. This potential becomes the leading commodity. Capture fisheries production until 2012 was 8624.10 tons. It was more than the previous year that is $7.009,8$ tons, including the commodity of milkfish. Local government in Pangkep, today maximizes the commodities of fish and seaweed, at least to glance for export. Local government provides serious attention to the development of centers of fish and seaweed. Therefore, the quality of these leading products will be increasingly enhanced. Development of milkfish and seaweed has a multiplier effect on other economic development.

\subsection{The Potential in the Agricultural Sector}

In the agricultural sector, Pangkep has Peanut, Soybean, Rice, and some major commodity crops such as pomelo. Based on the calculation of fixed numbers of South Sulawesi province in 2012, rice production in Pangkep was increased until it reached 15.51 percent with the achievement of production 138221 tons of milled rice or GKG. If it is compared to the year 2011, Pangkep can produce about 119.664 tons GKG. The agricultural sector could boost economic growth, which is getting increased from 6.3 percent to 9.2 percent. In addition to rice, fish, milkfish and seaweed, Pangkep is also famous for its leading commodity called ' lemo loppona ' (pamelo).

Tabel 2. Data of agricultural potential of pomelo in Pangkep

\begin{tabular}{|c|c|c|c|c|c|c|}
\hline \multirow{2}{*}{ Year } & \multirow{2}{*}{ Plants (Ha) } & \multirow{2}{*}{ Populations (Trees) } & \multicolumn{2}{|c|}{ Productive Plants } & \multirow{2}{*}{ Provitas (Kw/ Phn) } & \multirow{2}{*}{ Production (Ton) } \\
\cline { 4 - 5 } & & & $\%$ & trees & & \\
\hline 2004 & 653 & 114.188 & 57.6 & 66.632 & 1.21 & 8.543 \\
\hline 2005 & 727 & 127.155 & 54 & 68.224 & 1.24 & 8.953 \\
\hline 2006 & 868 & 151.808 & 48 & 73.107 & 1.28 & 9.926 \\
\hline 2007 & 944 & 165.147 & 47 & 88.061 & 1.34 & 13.068 \\
\hline 2008 & 1.067 & 186.625 & 58 & 107.670 & 1.33 & 15.953 \\
\hline 2009 & 1.159 & 189.764 & 58 & 110.281 & 1.36 & 16.889 \\
\hline 2010 & 1.191 & 208.377 & 54 & 114.379 & 1.23 & 16.436 \\
\hline 2011 & 1.265 & 222.977 & 57 & 124.270 & 0.56 & 8.405 \\
\hline 2012 & 1274 & 208.377 & 62 & 181.767 & 1.33 & 24.175 \\
\hline
\end{tabular}

Source: Central Bureau of Statistics in Pangkep Regency, 2013(11) 


\subsection{Public Participation in the Development of Regional Potential}

Public participation can be interpreted as a willingness to participate in the process of development or public participation in the process of identifying the problem and the potential that exists in the public, the selection and decision-making about alternative solutions to deal with the problem, the implementation of efforts to resolve the problem, and public involvement in the process of evaluating the changes which occur. The leading potential of the region will be explored and well managed if it is supported by the public participation.

Public as local residents can find out the sectors of the industry which can be used as leading sectors of regional potential and can produce additional revenue for them. Therefore, development of public participation is an approach to the community empowerment program that aims at improving regional economic growth. The development of public participation can be seen from some of the qualitative indicators. First, how is public involvement (community leaders and businessmen) in formulating and drafting of potential areas such as natural resource potential, agriculture, tourism, and mining? Second, do the public often participate in attending formulation and preparation of the regional potential? Third, do the public often participate in attending meetings, seminars, and workshops in the formulation of regional potential? Fourth, do the thoughts and ideas of the public always lead to the development of the potential of the region? Fifth, do the public involved in thinking about the importance of the investor in the development of the potential of the area?

In Pangkep regency, public participation is realized by forming the group of agriculture and fisheries as leading potential. The group of agriculture focuses on the areas of natural resource management, such as the potential of pamelo plantations that could advance the regional income in Pangkep. The group of fisheries focuses on the development of shrimp and fish. Most of the administrators group and members of the public as fish farmers revealed that they do not participate. They felt excluded from meetings held by the local government unless there are public complaints about the spread of disease outbreaks (viruses) shrimp, which hit the fish farmers. Even if there is a meeting, it is limited to the discussion of development plans or Musrembang. They provide their opinions, but they are never involved following-up in the form of the preparation and formulation. Likewise, if there is a problem in agriculture, no announcement. Even they do not know and never referred to whether or not there is a program of the government. The public participation in the form of thinking in developing the potential of the area, especially the maintenance and management of the plantation has been carried out maximally. However, it is often constrained by marketing of the commodity because the public assume that they are less given the space to be able to market the results of such natural resources properly. It means that the responsibility and participation of the public in conveying their ideas especially in the improvement of agriculture have become a collective consciousness of them for the advancement of Pangkep district as one of the ways to improve the welfare of the community in the development of the region.

In addition, the idea of the public to attract investors both local and national investors has become a desire, because in fact the public judge that the influx of investors is a thing that is very important to help the lack of funds that is needed. For them, the presence of investors will be able to lighten and help capital venture that they develop. However, they do not know how to invite investors so that the fisheries production particularly fish pond cannot be marketed properly. If they know the way, they will try to invite investors. Limitations of network and knowledge make investors less interested in managing the natural resources that exist. It means that the public should continue to be given the knowledge and understanding of how to communicate and develop themselves, in order to have the maximum ability to participate in regional development. Communication of local authorities provides information to the public so that they can feel the expected cooperation properly.

The cause of the lack of public participation in the development potential of the area is a closed information from local authorities and the lack of meetings with them. The information about the potential sources of the region that they get is obtained through discussions with groups of society. Even, it is rarely conducted unless there are problems complained of by the public. The lack of communication and information between the government and the public resulted in the lack of public space to make corrections and improvements in the formulation of the potential of the region.

However, public participation in following the news and information in the media is always performed. Based on that information, the public have a reference to explore the potential sources of the region. In addition, initiatives to communicate to legislators when doing recess, to businessmen and academics through seminars on the resources that will be explored is often performed. However, follow-up of the results of the meeting is less implemented.

Results of the study explained that the issue of public powerlessness is not always due to lack of capital although the capital is still necessitated. However, it is more due to awareness and work ethic that have not been awakened to be out of the faced economic problems. Therefore, in this study, there are at least four external interventions that are required. The first is the creation of job opportunities and business development. The second is motivation assistance in the form of knowledge and skills. The third is social protection. The fourth is the protection of business assets as human 
development and not as an expense of development.

\section{Conclusion}

Public participation in the agricultural sector has become the collective consciousness of progress in Pangkep. Thus, although they are not directly involved in extracting ideas related to the development of agriculture and plantations to improve the welfare of the community, the maintenance and management of agricultural products have been carried out maximally. The problem is that the farmer groups are less given space to market their existing products.

In the fisheries sector, fish farmers are still less involved in the meetings implemented by the local government. Therefore, they do not get enough information, especially regarding how to invite the investors so that the results of fishery production can be marketed properly.

\section{References}

Badan Pusat Statistik. (2012). Statistik Daerah Kabupaten Pangkajene dan Kepulauan. Penerbit BPS Kabupaten Pangkajene dan Kepulauan.

Badan Pusat Statistik. (2012). Statistik Daerah Kabupaten Pangkajene dan Kepulauan. Penerbit BPS Kabupaten Pangkajene dan KepulauanSuparmoko, M. (2002). Ekonomi Publik untuk Keuangan dan Pembangunan Daerah. Yogyakarta: Andi Offset.

Bank Dunia. (2007). Era Baru dalam Pengentasan Kemiskinan di Indonesia. (Translated) Penerbit: The World Bank.

Bryant, C \& White, L.G. (1982). Managing Development in the Third World. Boulder Colorado: Westview Press.

Mubyarto. (1984). Strategi Pembangunan Pedesaan. Yogyakarta: P3PK UGM.

Suparmoko, M. (2002). Ekonomi Publik untuk Keuangan dan Pembangunan Daerah. Yogyakarta: Andi Offset

Sumiharjo, Tumar. (2008). Penyelenggaraan Pemerintahan Daerah melalui Pengembangan Daya Saing Berbasis Potensi Daerah. Bandung: Fokus Media.

Tomo, Alamsyah. (2012). Pengembangan Potensi Daerah Berbasis Unggulan di Era Otonomi Daerah, Kasus Kabupaten Jeneponto (Makalah). Program Pascasarjana Magister Adminisatrasi Publik, Universitas Muhammadiyah Makassar.

Tomo, Alamsyah. (2012). Pengembangan Potensi Daerah Berbasis Unggulan di Era Otonomi Daerah, Kasus Kabupaten Jeneponto (Paper). Program Pascasarjana Magister Adminisatrasi Publik, Universitas Muhammadiyah Makassar.

Triyuwono Iwan \& Erani, Yustika Ahmad. (2003). Emansipasi Nilai Local Ekonomi \& Bisnis Pasca Sentralisasi Pembangunan. Malang: Bayumedia Publishing.Uphoff, N. (1988). Local Institutional Development. Fransisco: Cornell University Press.

Uphoff,. N. (1988). Local Institutional Development. Fransisco: Cornell University Press. 